\title{
Review
}

\section{The Radical Luhmann}

\author{
Hans-Georg Moeller \\ Columbia University Press, New York, 2012, xiii +168 pp., $\$ 26.00 / £ 18.00$, \\ ISBN: 978-0231153799
}

Contemporary Political Theory (2015) 14, e22-e26. doi:10.1057/cpt.2014.40; published online 28 October 2014

Hans-Georg Moeller's The Radical Luhmann treats the collected works of German sociologist Niklas Luhmann (1927-1998) through the convincingly insightful terminology of radicalism. With the main argument coming in at a lean 119 pages, Moeller's book may not be exhaustive, but it is efficient and effective in detailing the approach, attitude and arguments that Luhmann brings to the Western intellectual tradition. In engaging contemporary issues through Luhmann's theoretical model, Moeller rephrases Luhmann's arguments in accessible language without losing their complexity. He shows equal care and expertise in placing Luhmann into conversation with thinkers from Plato to Wittgenstein.

Moeller begins with the proposition that Luhmann's theory is more radical than it is generally recognized to be, and attributes the widespread misrecognition not just to Luhmann's ostensibly 'soporific' style (p. 10), but also to the fact that Luhmann's radicalism is not user-friendly: It does not come with a Kuschelecke or cuddling corner 'that allows readers to feel comforted and cozy, relaxed and warm' (p. 105). Instead Luhmann offers theoretically more rigorous and less comforting options. In chapter one, Moeller explains how Luhmann successfully joins ongoing theoretical debates in a 'Trojan Horse'; that is, he cloaks his texts in the jargon of the Frankfurt School branch of critical theory, but inflects it in opposition to the doctrine of rational deliberation (pp. 3-9). His cover is secured by both disciplinary factors and attitudinal ones, as Moeller goes on to explain in chapter two, 'Why He Wrote Such Bad Books'. In this chapter, Moeller takes an understandably malicious delight in vindicating Luhmann's bad writing (I take issue with the claim that Luhmann wrote poorly below). Luhmann's chosen discipline (sociology) and the discipline he engages extracurricularly (philosophy) encumber him, according to Moeller, with the duty to make himself a difficult read. To have credibility as a German academic, a 'clumsy writing style' (p. 14) is a must, and to follow in the footsteps of Hegel and Kant, his texts have 'to be sufficiently technical and abstract in order to be applied to an analysis of, basically, anything' (p. 12; italics in original). In other words, Luhmann speaks like everyone else in sociology and philosophy, and this renders

(c) 2015 Macmillan Publishers Ltd. 1470-8914 Contemporary Political Theory Vol. 14, 3, e22-e26 www.palgrave-journals.com/cpt/ 
the radicalism of his program more difficult to discern. His disciplinary inconspicuousness is supported by an attitudinal set that also makes his motives difficult to read: modesty, irony and equanimity (pp. 106-119). Thus undercover, Moeller argues that Luhmann avoids the need to refute the theoretical opposition directly and can instead 'smuggle' different, better analytical paradigms into ongoing debates in such a way that his theoretical adversaries are effectively helpless because Luhmann is already inside their theoretical architecture, dismantling it. Luhmann 'replace[s] dominating selfdescriptions, not only of social theory itself, but of society at large' (p. 5). For example he re-describes society as a whole as non-whole, as based on a logic of distinction, which formally cancels the Hegelian yearning for the reconciliation of differences.

Like others, Moeller characterizes Luhmann as a paradoxical figure who couples modesty in expressing the expected payoffs of his theory with a temerity implicit in the sheer scope of his enterprise. Luhmann is modest in that he promises no salvation to those who embrace his theory; like Wittgenstein, he offers the tools for making things a little less bad by reducing abuses of language (p. 51). Still it is difficult to deny a certain temerity behind what Luhmann himself calls a 'supertheory' (passim), that is, a theory capable of describing and offering an a posteriori explanation for all social phenomena, regardless of their regional complexion. Scholars have elsewhere noted Luhmann's 'ambitious modesty' (King and Schütz, 1994), which accompanies his interventions in sociological, as well as philosophical, political and ethical/ moral discussions.

Moeller deftly shows how the arguments he makes in one venue have ramifications in other venues. What Moeller calls the 'The Fourth Insult' in chapter three produces such a ripple effect. The fourth insult refers to the position to which Moeller assigns Luhmann in what he crafts as a history of philosophical offense. First Copernicus removed the earth from the universe's center (the cosmological insult); then Darwin suggested 'that man was not the crown of creation' (the biological insult); next, with the id, Freud debunked the illusions of free will and self-control (the psychological insult); and finally Luhmann issues the sociological insult. Luhmann argues that society has no central control room, but is in effect a rudderless ship whose helm is for show and the placation of fools (p. 28). Living, thinking humans cannot influence social evolution. In fact 'the human,' is an antiquated concept of questionable value for sociology. Luhmann insists that the conscious and physical components of the human are of no interest to sociology because they are unobservable. That is, there is no feedback loop between what is meant and felt - between mind and heart - and what is said. Thus sociology should stick to observing communication, which is the basic unit of the social in Luhmann's system, and the only phenomenon that sociology's instrumentality can register (pp. 39-40).

By situating Luhmann among philosophers in a pantheon of the highest order, Moeller can portray him as a plausible challenger to the Hegelian doctrine of necessity in chapter four, 'From Necessity to Contingency', and to Cartesian dualism in chapter five, 'The Last Footnote to Plato'. This move is not new. Peter Sloterdijk, 
for example, lists him among Schwellengrößen - or, awkwardly, 'epochal thinkers' - like Nietzsche, Marx, Darwin, Saussure, Heidegger, Levi-Strauss, Adorno, Chomsky and Foucault $(2000$, p. 3) in order to explain how the name Luhmann marks a 'caesura as well as the time after it' (sowohl die Zäsur als auch die Zeit nach ihr; 2000, p. 4). Hegelian necessity becomes irrecoverable after Luhmann has shown that Hegel's argument in the Phenomenology of Spirit does not lead to 'a coherent story, with a unified whole' (p. 45). When spirit (Geist) settles down to tell a tale, its narrative becomes contingent upon context: The insights of spirit are therefore not only not necessary, but in fact highly unlikely - the story could always be told otherwise. Luhmann's solution to Cartesian mind-body dualism is not to reconcile the body and mind nor to advocate the managerial function of one over the other, but rather to introduce a third component of the human condition: the communicative (p. 56).

In explaining what the communicative is, Moeller cites some of Luhmann's most renown fighting words: 'Only communication can communicate' (p. 23), which is taken from his essay 'Was ist Kommunikation?' ('What is Communication?'; 2005, p. 38). In this text Luhmann rejects the sender-message-receiver model in all its forms and replaces it with another tripartite model: information-utterance-understanding. Luhmann's model decenters the subject, excluding the direct involvement of the human (sender/ receiver) and replacing it with components that consist of symbols, words or sentences (communicative media). These components give form through the selection of information (taken from previous communication), utterance (articulation of information) and understanding (as the difference between information and utterance). The human mind-body may irritate these selections, but not in a way that allows original expression. The human thus becomes a plurality of structurally coupled systems, and it makes little sense to talk of unity or fragmentation when one is interested in how these systems coexist in a state of mutual inscrutability.

In chapters 6-9, Moeller goes on to explain how Luhmann's ideas of contingency and of limited human agency, together with a constructivist theory of communication, have radical consequences for ethics and political theory. In chapter six, 'Ecological Evolution', Moeller makes the provocative argument that theorists like Jürgen Habermas, who believe that they can draft plans for a better society, share the same (conservative) dogmas as religious creationists. Moeller recognizes the progressive potential behind Luhmann's concept of social evolution. Like Darwin, but without the necessity of biological evolution, Luhmann allows for deviation (variation), selection and stabilization. Evolution never shuts the door on future deviation but instead opens it to a freer social existence.

That things can always be otherwise also plays into the thinking behind chapter seven, with the provocatively paradoxical title, 'Constructivism as Postmodernist Realism'. Moeller looks at Luhmann's 'radical constructivism' (p. 78) as another expression of both modesty and boldness. His modesty appears in the premise that 
neither he nor anyone else can exit society in order to describe it. For Luhmann (and Moeller) describing is constructing; it is giving new contours to our social landscapes. If the most realist construction is to describe ourselves as rats in the maze, then we must be honest and reveal the point from which we observe the other rats (p. 81). Luhmann claims a particular boldness for being willing to reveal and account for how he himself is implicated. Moeller endorses Luhmann's selfappraisal, explaining that one reason Luhmann's theory is more robust is because it seeks a rigorous understanding of its own fallibility, and can better come to rights in a 'topsy-turvy' world (p. 86).

Chapter eight features an account of politics' limited effectiveness (pp. 88-104). The political system cannot issue authoritative statements in the systems of economics, art, religion and so on. It can only 'irritate' discussions occurring there, which may move them in a general direction, but not with any precision. Finally, in chapter nine, 'Neither Hope nor Fear', Moeller describes how Luhmann distances himself from '[n]onironic shock and awe morality' (p. 116) that was and still is en vogue on the German intellectual scene. Our current society is not hell, and no heaven will be attained on earth - thus we need to focus on the abuses and merits of what we have, reducing the former and multiplying the latter where possible. Moeller sees this as a radical step away from the self-congratulatory condemnation of 'corrupt' social formations that have made theorists like Jürgen Habermas and Ulrich Beck more popular with readers more interested in ailments than therapies (p. 115).

While I recommend this book enthusiastically for anyone interested in Luhmann or Big Theory, I have a personal reservation concerning chapter two, 'Why He Wrote Such Bad Books'. This pun on a section of Nietzsche's Ecce Homo cannot be regarded as designating a critical consensus among Luhmann's readers. Once Luhmann has established himself in the sociological discourse, he quickly dispenses with the dry German academic style. There is a clear difference between his style in the 1960s and 1970s, and the more reader-friendly, often poetic style of the 1980s and 1990s. I have discussed the elegant poetic quality of his rhetoric at some length (Cesaratto, 2013, pp. 112-115). In addition, in a study that recommends Luhmann's work to literary studies, Dieter Schwanitz issues a statement that directly opposes Moeller's claim. To make his point Schwanitz stages a discussion of Luhmann's Social Systems between Sherlock Holmes and Watson:

HOLMES: This is a German professor that all other German professors find unreadable.

WATSON: Then he must either have scaled the peak of unreadability or be especially readable.

HOLMES: The latter. A highly stimulating author. Highly recommended for people in need of a challenge. (Schwanitz, 1990, p. 36) 
Moeller is one reader who was more than adequate to that challenge. Moreover, he deftly demonstrates to North American readers the contributions Luhmann might make to sociology, philosophy, political theory and theory with a capital T.

\section{References}

Cesaratto, T. (2013) Luhmann, all too Luhmann: Niklas Luhmann, Nietzsche, and the human. In: A. La Cour and A. Philippopoulos-Mihalopoulos (eds.) Luhmann Observed: Radical Theoretical Encounters. London: Palgrave Macmillan, pp. 108-134.

King, M. and Schütz, A. (1994) The ambitious modesty of Niklas Luhmann. Journal of Law and Society 21(3): 261-287.

Luhmann, N. (2005) Was ist Kommunikation? In: Soziologische Aufklärung, Vol. 6. Wiesbaden, Germany: VS Verlag, pp. 109-120.

Schwanitz, D. (1990) Systemtheorie und Literatur: Ein neues Paradigma. Opladen, Germany: Westdeutscher Verlag.

Sloterdijk, P. (2000) Der Anwalt des Teufels. Niklas Luhmann und der Egoismus der Systeme. Soziale Systeme 6(1): 3-38.

Todd Cesaratto

University of Arkansas, Fayetteville, USA 